This item was submitted to Loughborough's Research Repository by the author.

Items in Figshare are protected by copyright, with all rights reserved, unless otherwise indicated.

\title{
Creating sustainable value through remanufacturing: Three industry cases
}

PLEASE CITE THE PUBLISHED VERSION

https://doi.org/10.1016/j.jclepro.2019.01.301

PUBLISHER

(c) Elsevier

VERSION

AM (Accepted Manuscript)

PUBLISHER STATEMENT

This paper was accepted for publication in the journal Journal of Cleaner Production and the definitive published version is available at https://doi.org/10.1016/j.jclepro.2019.01.301.

LICENCE

CC BY-NC-ND 4.0

\section{REPOSITORY RECORD}

Jensen, Jonas P., Sharon Prendeville, Nancy Bocken, and David Peck. 2019. "Creating Sustainable Value Through Remanufacturing: Three Industry Cases". figshare. https://hdl.handle.net/2134/37167. 


\title{
Wordcount (everything included): 10.607 words
}

\section{Creating Sustainable Value through Remanufacturing: Three Industry Cases}

Jonas P., Jensen ${ }^{1}$, Sharon M. Prendeville ${ }^{2}$,Nancy M.P. Bocken ${ }^{3}$, David Peck ${ }^{4}$

\author{
IDepartment of Planning, Aalborg University, Denmark, \\ ${ }^{2}$ Institute of Design Innovation, Loughborough University, London, United Kingdom, \\ ${ }^{3}$ The International Institute for Industrial Environmental Economics, Lund University, Sweden, \\ Faculty of Industrial Design Engineering, TU Delft, Netherlands \\ ${ }^{4}$ Faculty of Architecture and Built Environment, TU Delft, Netherlands
}

Address correspondence to: Jonas Pagh Jensen, Department of Planning, Rendsburggade 14 Aalborg University, Aalborg, Denmark.E-mail: jonaspj@plan.aau.dk

Keywords: Circular Economy; Remanufacturing; Business Model Innovation; Sustainable Value Creation; Triple-bottom-line; Circular Business Models.

\section{Abstract}

Remanufacturing is proposed as a strategy to develop circular business models to manage resource loops in the future circular economy $(\mathrm{CE})$. If remanufacturing is to occupy a central role in the $\mathrm{CE}$ it needs to be considered from a series of complementary and synchronous business activities. Thus, the aim of this article is to investigate how such an integrated perspective can drive sustainable value creation within the context of remanufacturing business models. This is explored through three business cases: Philips Healthcare Refurbished Systems, Siemens Wind Power, and Orangebox. This 'integrated view' considers remanufacturing activities according to: product design and development; remanufacturing processes; value chain design and management; and marketing and consumer/user relationship. The research question asks, 'Can an integrated perspective drive sustainable value creation in remanufacturing contexts?' To answer this, the research maps a set of triple-bottom-line indicators across the chosen cases. The work contributes to the field by mapping a set of business mechanisms (e.g. warranties, service approaches, partnerships) that can be utilised to co-develop necessary activities in unison for a successful remanufacturing approach. In certain cases, remanufacturing has the potential to add to the triple-bottom-line through such an integrated approach. However, each of the firms are investing in remanufacturing predominantly for profitability and market protection measures and therefore environmental and social components of the triple-bottom-line must be proactively considered. 


\section{Introduction}

The circular economy (CE) champions a new type of economy, a closed loop system of production and consumption, which cycles resources (as feedstock) to reveal multiple and often shared value opportunities (Stahel, 1994; Braungart et al., 2008; EMF, 2013). Enthusiasm for the circular economy $(\mathrm{CE})$ is evident in its integration in international policies at supranational (e.g. European Union CE Roadmap (European Commission, 2015)), national (e.g. China's 11th and 12th Five Year Plans (Su et al., 2013)), as well as at the city-level (Prendeville et al., 2017). Companies are enticed by the (economic) promise of the CE (EMF, 2013) and have started to explore its potential (Geissdoerfer et al., 2017). However, circular economy requires a holistic approach that considers sustainability in the context of environmental and social impacts as well as economic ones, to avoid ending up as ‘just another perpetual motion dream' (Cullen, 2017) and has recently also been criticized by academics for being a 'collection of vague and separate ideas from several semi-scientific fields that needs scientific research' (Korhonen et al, 2018), where only limited progress has been accomplished regarding implementation due to various reasons e.g. hesitant company culture (Kircherr et al, 2018).

Remanufacturing is a central part of the CE, and according to Souza (2010) business approaches to remanufacturing are "immature" (Souza, 2010) with few viable business approaches identified despite many years of research (Lieder \& Rashid, 2016). Furthermore, few cases of remanufacturing in original equipment manufacturers (OEMs) have been presented (Ferguson \& Souza, 2010), indicating a need for further exploration if remanufacturing is to be realistically seen as a strategy to develop circular business models.

In light of this, this paper explores the development of remanufacturing activities in OEM businesses to assess if remanufacturing activities can spur sustainable business innovations. In this study, remanufacturing is taken as an integrated set of business activities (see 2.2), where value is explored from a triple-bottom-line perspective within three companies.

\section{Literature review of remanufacturing and business model innovation}

This section introduces the literature on remanufacturing, taking an integrated business perspective and explores how it can contribute to sustainable value creation.

\subsection{Remanufacturing as part of a $\mathrm{CE}$}

Remanufacturing is defined as the process of "returning a used product to at least its original performance with a warranty that is equivalent to or better than that of the newly 
manufactured product" (British Standards Institute, 2010). In the USA, the estimated economic contribution of remanufacturing is vast and is valued at $\$ 43$ billion (United States International Trade Commission, 2012). Remanufacturing has recently been enshrined in US law, which now stipulates the use of remanufactured parts within federal governmental vehicles. Similarly, a 2016 study undertaken by the European Remanufacturing Network (ERN) estimates the value of remanufacturing to the European economy at up to $\$ 111$ billion (ERN, 2016). However today, remanufacturing uptake in Europe is not yet widespread; the remanufacturing intensity (ratio of remanufacturing to new manufacturing) in Europe is estimated at 1.9\% (ERN, 2016) and in USA 2\% (United States International Trade Commission, 2012).

Remanufacturing has been co-opted within and positioned as a key strategy within CE models (EMF, 2013). This reframing of remanufacturing is important because as Blomsma \& Brennan (2017) found the advent of the CE provides as a value-adding alternative to 'waste management' practices. In a $\mathrm{CE}$, remanufacturing is a product life extension strategy to make products last longer (Bakker et al., 2014) by retaining them at the highest possible value for the longest possible time (Achterberg et al., 2016). This is predominantly achieved by combining innovation in products alongside innovation in business practices (Bakker et al., 2014; Bocken et al., 2015; Murray, 2017). Remanufacturing is highlighted as a desirable innovation strategy (Sinha et al., 2016) to slow resource loops. It requires the integration of design and business model innovation to be understood on those terms and as an integrated strategy of the company's business offerings (Opresnik and Taisch, 2015). Remanufacturing requires new forms of collaboration (such as multiple transactions between suppliers and producers and producers and purchasers/consumers) (Guide et al, 2003) to conceive and implement new circular business models in combination with new design approaches (Wells \& Seitz, 2005).

\subsection{An Integrated Perspective on Remanufacturing}

In the past remanufacturing research has focused on isolated or single issues e.g. uncertainty to correct initial fault diagnosis (Ijomah et al., 1999) various models for design of reverse logistics (RL) networks (Pokharel \& Mutha, 2009), optimal pricing of products (Mutha \& Pokharel, 2009), optimal process choice of flow of parts and products (Guo et al, 2014) as well as optimum planning of logistics (Garg et al, 2015). More recently, the literature on remanufacturing business is contained within the RL and closed-loop supply chain (CLSC) literature. These are supply chains that involve a reverse flow of products, components or materials back to the manufacturer (Ferguson \& Souza, 2016). Various perspectives on 
remanufacturing can be derived from the academic literature (see Table 1) illustrating that remanufacturing requires a series of integrated, mutually deployed activities, across a number of business areas (Lieder \& Rashid, 2016).

Table 1: Perspectives on remanufacturing from the academic literature

\begin{tabular}{|c|c|c|}
\hline Perspective & Description & Source \\
\hline $\begin{array}{l}\text { Activity-systems } \\
\text { perspective (technical } \\
\text { attributes emphasised) }\end{array}$ & $\begin{array}{l}\text { Combination of front-end (e.g. quality / } \\
\text { return rates), engine (e.g. RL), and back end } \\
\text { activities (e.g. remarket) }\end{array}$ & Guide \& Van Wassenhove (2009) \\
\hline $\begin{array}{l}\text { Process flow perspective } \\
\text { (relationship / links } \\
\text { between process steps) }\end{array}$ & $\begin{array}{l}\text { Combination of front-end (product returns } \\
\text { management), engine (operational issues), } \\
\text { and back end activities (market } \\
\text { development) }\end{array}$ & Guide \& van Wassenhove (2009) \\
\hline $\begin{array}{l}\text { External-Internal } \\
\text { Dimensions } \\
\text { (Operational factors } \\
\text { emphasised) }\end{array}$ & $\begin{array}{l}\text { Internal (sustainability, customer demand, } \\
\text { suitability, profitability, competitiveness) } \\
\text { internal (Business, design, supply chain } \\
\text { relationships, socio-psychological) }\end{array}$ & Hatcher et al. (2014) \\
\hline $\begin{array}{l}\text { General-system } \\
\text { elements } \\
\text { (Elements and sub- } \\
\text { elements comprise } \\
\text { integrate view) }\end{array}$ & $\begin{array}{l}\text { Design for remanufacturing; Reverse supply } \\
\text { chain (Acquisition/relationship with the core } \\
\text { supplier, RL); Information flow in the } \\
\text { remanufacturing system; Employees' } \\
\text { knowledge and skills in remanufacturing; } \\
\text { Remanufacturing operation; } \\
\text { Commercialization of the remanufactured } \\
\text { product }\end{array}$ & $\begin{array}{l}\text { Barquet et al (2016) building on } \\
\text { Östlin (2008) }\end{array}$ \\
\hline $\begin{array}{l}\text { Integrated Perspective } \\
\text { (coordinated } \\
\text { management for value } \\
\text { creation) }\end{array}$ & $\begin{array}{l}\text { Product design and development; Value } \\
\text { chain design \& management; Manufacturing } \\
\text { and remanufacturing processes; } \\
\text { Marketing and consumer behaviour } \\
\text { (Adopted view by the paper, see Figure 1) }\end{array}$ & $\begin{array}{l}\text { Rashid et al, } 2013 \\
\text { Lieder \& Rashid } 2016\end{array}$ \\
\hline
\end{tabular}

Remanufacturing requires business models based on shared value propositions (Wells \& Seitz, 2005) through extended customer and supplier relationships and alternative new financial mechanisms such as rebates (Pigosso et al., 2009) to retain product control. In the literature, $\mathrm{RL}$, closed-loop supply chains and remanufacturing activities are relevant to those industries that wants to shift to an alternative circular or 'closed-loop business model (Gallo et al, 2012). However, such business models focusing on circularity, contrary to their perceived benefits are not that widespread in industry (Linder \& Williander, 2015) due to related uncertainties and 
risks (e.g. timespan of business model, tied-in capital, return flow challenges and unpredictability) and as such are not well understood.

In this article, this is addressed by adopting an existing model for integrated remanufacturing activities that includes product design and development; manufacturing and remanufacturing process; value chain design and management; and marketing and consumer/user relationship.

\subsection{Sustainable Value Creation through Remanufacturing}

Creating sustainable value in firms means to generate triple-bottom-line benefits for the environment, society and economy (Evans et al, 2017), being able to measure this performance is also a necessity (Elkington, 1997). In the absence of universal triple-bottom-line indicators, this general framework can be adapted to contextual needs (Slaper and Hall, 2011). Several studies investigate triple-bottom-line indicators. In this study, we combine the work of Svensson et al., (2016) who identify a set of indicators through a systematic review with that of Agrawal et al, (2016) who list a set of indicators related to reverse logistics. The indicators merged and compiled into Table 2.

Table 2: Triple-bottom-line indicators compiled from Elkington (1997), Agrawal et al (2016) and Svensson et al (2016)

\begin{tabular}{llllll}
\hline Indicator & $\begin{array}{c}\text { Economic } \\
\text { Measured as }\end{array}$ & Indicator & $\begin{array}{c}\text { Social } \\
\text { Measured as }\end{array}$ & Indicator & $\begin{array}{c}\text { Environmental } \\
\text { Measured as }\end{array}$ \\
\hline Profitability & EBIT margin $(\%)$ & Organisational support & Perceived support level & Environmental impact & Ecosystem quality \\
Annual sales & Revenue $(\$)$ & Corporate culture & Knowledge on mission and vision (\%) & Climate change and global warming & CO2-impact of business \\
Cost reduction & Product cost (\$) & Corporate reputation & Global reputation score & Multitude of initiatives & Number of environmental effects \\
Competitiveness & EBIT relative to peers (\%) & Employment (stability) & Retention rate (years) & Product dematerialization & Resource use per delivered function \\
Brand value & Perceived value (\%) & Job creation & Number of employees (\#) & Product decarbonization & CO2-emission per delivered function \\
Spin-offs & Number of spin-offs (\#) & & & & \\
\hline
\end{tabular}

A claimed benefit of remanufacturing is its potential for preserving the embedded value (energy, materials and labor) of products (Vogtlander et al, 2017) which in turn, can often achieve energy and carbon savings (Gutowski, 2011) and generate jobs (Rashid et al., 2013). From an economic perspective, it has been highlighted for its potential to reduce production costs, increase efficiency, protect industry against volatile material prices and supply disruptions issues (Graedel 2009, Graedel et al 2012 \& 2013), and an increasing awareness of the potential impacts of future material criticality (Peck et al., 2015, Peck, 2016). Similarly, studies on business competitiveness have been undertaken that broadly conclude that 
remanufacturing can be a viable business practice that can benefit pricing and market segmentation on selected product groups (Abbey et al., 2015).

While remanufacturing is beneficial for material resource conservation by slowing down resource use, a given case needs to be analysed related to its context to identify its environmental impacts (Lindahl et al., 2006) e.g. in the case of products with an intensive energy-use phase, innovation in energy efficiency use may outweigh the benefits of remanufacturing devices already on the market - unless the energy consuming part is replaced (Gutowski, 2011; Gutowski et al, 2011). Such dilemmas are a common challenge for companies and business model innovation has been shown to help reconcile these decisions (Prendeville et al., 2017). As such, evaluations of remanufacturing activities from a triple-bottom-line life cycle approach are critical. It can potentially encourage more business activity in this area (Allwood et al, 2011). Nevertheless, there are contextual limitations to where and when such benefits are realised as well as risk factors for many stakeholders.

\subsection{Research Gap}

Remanufacturing faces several challenges (Ferguson \& Souza, 2010). From an academic viewpoint, there is an over-focus on incremental improvements in modelling remanufacturing systems as well as a lack of known viable business models (Lieder \& Rashid, 2016). Indeed, many existing remanufacturing studies focus on measuring the environmental benefits of remanufacturing, such as eco-efficiency of personal computers and mobile phones (QuariguasiFrota-Neto \& Bloemhof, 2012) or life cycle assessment (LCA) of diesel engines (Liu et al., 2014), and compressors (Biswas et al., 2013), but there is gap in measuring on triple-bottomline indicators. Despite being highlighted as the ultimate form of recycling since the 1990s (Lund, 1996), Souza (2013) states that to-date business-focused remanufacturing research has only 'scratched the surface' and is limited by single indicators.

This study takes the premise that firstly for remanufacturing to be successful an integrated perspective on business activities is required and secondly, triple-bottom-line indicators can contribute to consciously measure the sustainability of the innovation to ensure that remanufacturing activities create value sustainably and does not lead to 'circular economy rebound' (Zink \& Geyer, 2017) where activities in fact lead to more consumption of materials and products. Therefore, this study takes an 'integrated' perspective to offer new insights into strategic innovation for sustainable value creation through remanufacturing by addressing the following question: 'Can an integrated perspective drive sustainable value creation in 
remanufacturing contexts?' Figure 1 conceptualises this by combining the integrated set of activities a business must undertake to successfully do remanufacturing. This should be constrained by suitable triple-bottom-line indicators for sustainable value creation.

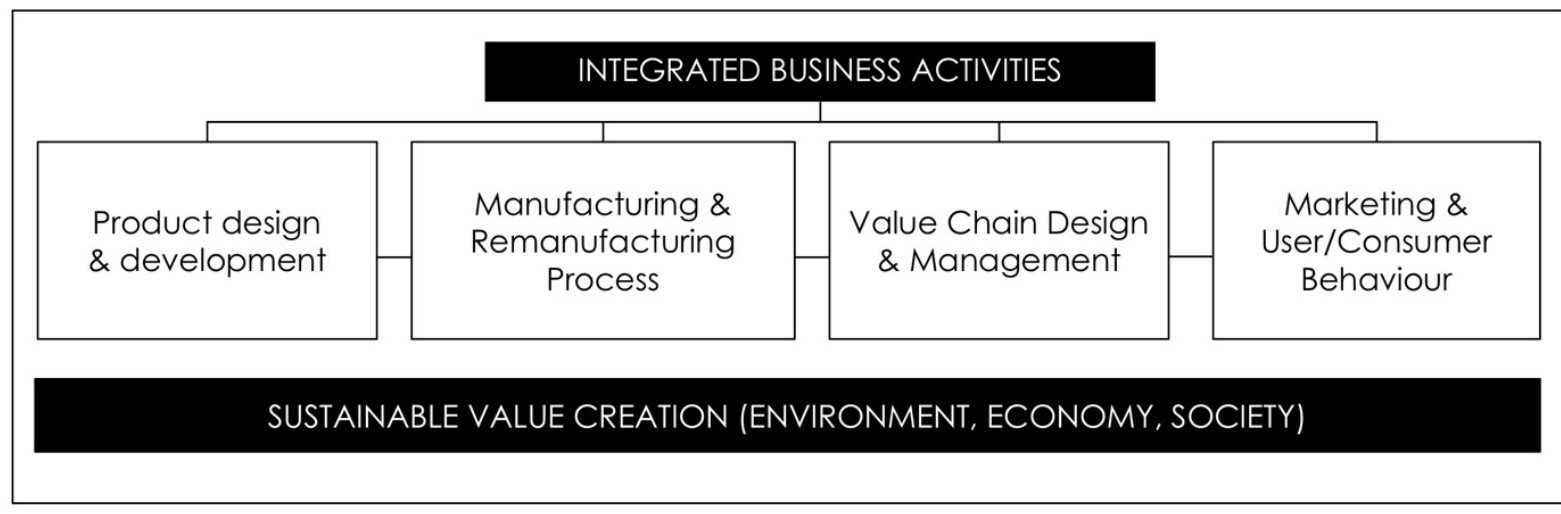

Fig. 1 Conceptual Framework on Integrated Business Activities and Triple-bottom-line Sustainable Value Creation Adapted from Lieder \& Rashid, 2016; Brundtland, Elkington 1997, Ellen MacArthur Foundation 2013.

\section{Methodology}

Three business case studies on remanufacturing at Philips Healthcare Refurbished Systems (RS), Siemens Wind Power (SWP) and Orangebox are presented in this paper. The scope of the study is limited to OEMs.

The cases represent a range of distinct remanufacturing approaches across key sectors with high market potential for remanufacturing: furniture, healthcare, and renewable energy (Ellen Macarthur Foundation, 2015b). The chosen cases provide examples of OEMs that approach remanufacturing by undertaking activities across several business areas (an integrated approach) and offer the potential to reveal the relationship between remanufacturing elements. The remanufacturing cases are underpinned by LCA to inform its internal decision-making processes, and therefore, the quantitative impact assessment is omitted from this study.

Multiple semi-structured interviews were conducted over the phone and face-to-face with senior members at the firms, to understand the remanufacturing process and the strategic ideas motivating the remanufacturing activities and how it affects design and business model strategies (Table 3). In total, three site visits were undertaken to Philips and Orangebox. In the case of SWP, the data was gathered during longitudinal participatory research with the company. The structure of the interviews was thematic based to understand i) the market, ii) the company and iii) the integrated approach to remanufacturing (see clarification of structure in section 4) of each of the companies. However, the interviews were done by different people 
and the possibility of adapting the theme-based structure, was possible. For each of the company a key employee related to remanufacturing was interviewed. The interviews are supported by a review of grey literature including market reports and company reports. These methods are summarised in Table 3. The cases are analysed thematically across and within-cases, with respect to each firm's series of activities towards remanufacturing as well as its propensity for sustainable value creation of those activities. The cases are structured around the following themes:

1. International market, context and setting of the case, considering the company and its sustainability activities to-date

2. Integrated business activities for remanufacturing including product design and development, the remanufacturing process, value chain design and management and marketing and consumer/user relationship

3. Sustainable value creation with focus on triple-bottom-line benefits

\section{Table 3: Description of Case Study Methods}

\begin{tabular}{|c|c|c|}
\hline Firm & Method & Purpose \\
\hline Orangebox & $\begin{array}{l}\text { - } \quad \text { Longitudinal case study } \\
\text { - In-depth semi-structured } \\
\text { interview (1 x } 60 \text { mins) } \\
\text { - } \text { Follow-up phone-calls (1 x } 15 \\
\text { mins) } \\
\text { - Participatory LCA using abridged } \\
\text { software and carbon meta- } \\
\text { analysis } \\
\text { - Site visits (2) } \\
\text { Desk research reviewed: } \\
\text { - Project reports } \\
\text { - Company literature }\end{array}$ & $\begin{array}{l}\text { Project overview, context, key } \\
\text { design and business decisions, } \\
\text { commercial benefits } \\
\text { - Clarification of economic data } \\
\text { - Environmental data } \\
\text { - Product descriptions }\end{array}$ \\
\hline $\begin{array}{l}\text { Siemens Wind } \\
\text { Power (SWP) }\end{array}$ & $\begin{array}{l}\text { - Longitudinal case study } \\
\text { - Observation } \\
\text { - In-depth semi-structured } \\
\text { interview ( } 3 \text { x } 30 \text { mins }) \\
\text { - } \text { Participatory LCA using abridged } \\
\text { software and carbon meta- } \\
\text { analysis }\end{array}$ & $\begin{array}{l}\text { Project overview, context, key } \\
\text { design and business decisions, } \\
\text { commercial benefits and economic } \\
\text { data } \\
\text { - Environmental data } \\
\text { - Product descriptions }\end{array}$ \\
\hline
\end{tabular}




\begin{tabular}{|c|c|c|}
\hline & $\begin{array}{l}\text { Desk research reviewed: } \\
\text { - Project reports } \\
\text { - Company literature }\end{array}$ & \\
\hline \multirow[t]{2}{*}{$\begin{array}{l}\text { Philips } \\
\text { Healthcare RS }\end{array}$} & $\begin{array}{l}\text { - In-depth semi-structured } \\
\text { interview (1 x } 45 \text { mins }) \\
\text { - } \quad \text { Site visits (1) } \\
\text { - } \quad \text { Follow-up phone-calls (1) }\end{array}$ & $\begin{array}{l}\text { Project overview and context, key } \\
\text { design decisions, commercial } \\
\text { benefits } \\
\text { - Clarification of economic and } \\
\text { environmental data }\end{array}$ \\
\hline & $\begin{array}{l}\text { Desk research reviewed: } \\
\text { - Project reports } \\
\text { - Company literature }\end{array}$ & - Product descriptions \\
\hline
\end{tabular}

\section{Results}

\subsection{Firm A: Siemens Wind Power (SWP)}

\subsubsection{The Global Renewable Energy Market}

Between 2005 and 2014 the wind energy sector saw rapid growth of 23\% (GWEC, 2015). Globally, 2014 marked a breaking point for wind energy installations, which surpassed $50 \mathrm{GW}$ and total investments in clean energy reached $€ 277$ billion (GWEC, 2015). In 2014 the wind sector accounted for $€ 88.9$ billion (GWEC, 2015).

\subsubsection{Firm Overview}

SWP is part of the Siemens AG conglomerate. Siemens AG acquired Danish wind company Bonus A/S in 2004 and has since expanded from 600 employees to over 10,000 employees. SWP is today one of the largest manufacturers of wind turbines in the world (Make Consulting, 2015; BTM Navigant, 2015).

Wind turbine technology dates back thousands of years (Kaldellis \& Zafirakis, 2011) and is today used as power plants. The technology has developed rapidly in recent years and has grown in both size and potential energy output. Modern wind turbines have a nameplate capacity of up to 9,5MW and an expected lifetime of 20-25 years (Siemens, 2015).

\subsubsection{Integrated Business Activities at SWP}

\section{Product design and development}

SWP developed a 'power curve upgrade package' (PCUP) to boost the efficiency of turbine blades and increase energy production (and reduce noise emissions). The add-ons: DinoTail (which mimics the back plates of a Stegosaurus), DinoShell and Vortex Generator, are designed 
to increase lift, improving aerodynamic performance and thereby increasing the annual energy production by $1.5 \%$. For SWP, remanufacturing is a novel business approach and the PCUP was not intentionally designed for remanufacturing purposes.

'Since the original development of the turbines, we have developed improvements to the blade technology. By strategic placement of the add-on components, it's possible to get more energy out of the same infrastructure '(Interview with blade engineer, 2015)

\section{Remanufacturing Process}

The PCUP is produced at suppliers and then sold and installed through the service organization. This includes installation of the PCUP on the blades and tower by skilled engineers. So far, this is limited to certain turbine types of SWP's own production line and does not extend to other OEMs' products. Due to the nature of the core machine the remanufacturing process requires on-site installation of the PCUP, so therefore limited RL systems are needed.

\section{Value chain design and management}

SWP develops, manufactures, sells and services wind turbines as its core business activity. The main competitive driver in the energy sector is the price of energy, so delivering products with low cost and high efficiency is crucial in this market. To-date SWP has focused on the sale of turbines and sale of service agreements, where it endeavors to deliver a quality product by ensuring high performance of the wind park during its lifetime, by guarantee. However, as a wind park owner is unlikely to repower a site (i.e. install new turbines on the same site) until the initial return-on-investment has been earned, the monetary value creation for SWP during this timeframe is through servicing contracts and the development of innovations such as the PCUP.

\section{Marketing and Client Relationship}

SWP is in ongoing contact with its customers for an extended period through a service agreement. This arrangement offers opportunities that can lead to the sale of the PCUP. Through on-site servicing and by including remanufacturing in the business model, it is possible to approach the existing customer base with the newly developed add-on. The revenue is created through payments for the PCUP service. 


\subsubsection{Sustainable Value Creation at SWP}

This novel approach is an extension to an already established servicing strategy. The benefit of this is extra revenue generation, increased energy production and access to the latest technology (benefit to the customer) and less impact per energy unit produced. Increasing the annual energy production of a wind park is directly linked to its revenue generation. The payback period for the customer short, so during a lifetime the investment to install the PCUP is negligible in comparison to the potential increase in revenue generation (estimated 1.5-3\%) and the PCUP comes under its own warranty. As such, on-site remanufacturing can be an effective strategy for turbines in areas where (for example) height restrictions hinder new installations or where additional new turbines are not desired. This opens up new sales opportunities for SWP, which were not possible with traditional sales and service agreements. The PCUP has been installed in several onshore and offshore projects, demonstrating additional business opportunities and potential for diverse market uptake. Installing the PCUP on a $125 \mathrm{MW}$ wind park means that the extra energy will be enough for approximately 2,500 households.

Using published environmental product declarations of SWP turbines, it is documented that material use has the single-largest impact on the environment (Siemens Wind Power, 2014). The environmental impacts of the PCUP blades are negligible when compared with overall material use. This means an increase in resource efficiency (higher energy output per unit of material) which lowers the environmental impact per energy unit produced, so an environmental benefit associated with the PCUP is apparent. Table 4 summarises the triplebottom-line factors identified at SWP.

Table 4: Triple-bottom-line Factors at SWP

\begin{tabular}{|c|c|c|}
\hline Economic benefits & Environmental Benefits & Social Benefits \\
\hline 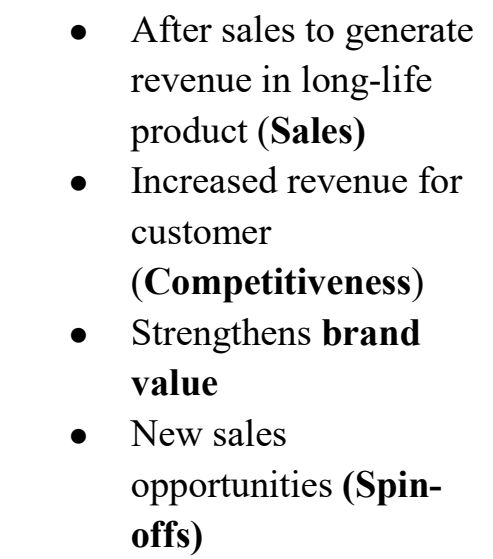 & $\begin{array}{l}\text { - } \begin{array}{l}\text { Reduced impacts (per } \\
\text { energy unit delivered to the } \\
\text { grid) (Product } \\
\text { decarbonisation) }\end{array} \\
\text { - Increase performance } \\
\text { efficiency (Climate } \\
\text { change) } \\
\text { - } \begin{array}{l}\text { Noise reduction (Multitude } \\
\text { of initiatives) }\end{array}\end{array}$ & 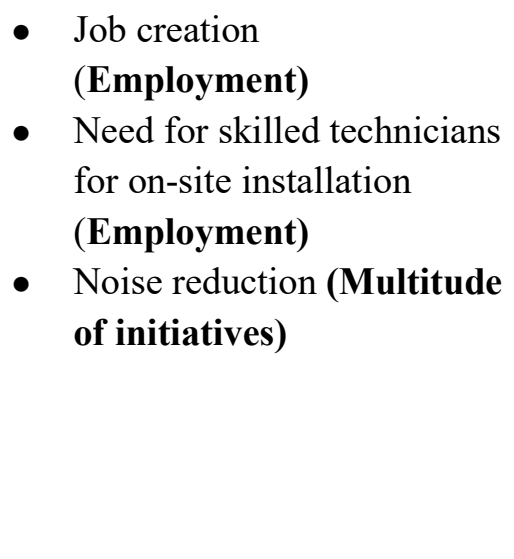 \\
\hline
\end{tabular}


- Market diversification

(Competitiveness)

- Mechanism to deploy

innovation to products

already on the market

(Spin-offs)

\subsection{Firm B: Orangebox}

\subsubsection{The Global Furniture Market}

The global furniture market is well developed. In 2012, it was estimated to constitute 1\% of the total of manufactured products and the whole sector was approximated at $€ 360,862 \mathrm{~m}$ (CEPS, 2014). The office furniture sector is valued at roughly 10 percent of the whole global furniture market (CEPS, 2014).

Until recently, task chairs sold into the UK market, lacked substantial design investment and were typically manufactured as kit-chairs, which were built from prefabricated subassemblies purchased off-the-shelf, assembled and sold under a branded company. The material use for office chairs has changed over the years from wood and steel, to Bakelite, to aluminium, nylon, polypropylene and technical textiles. The market for task chairs is mature, companies compete on price and therefore investment in design has increased to differentiate products in the market.

\subsubsection{Firm Overview}

Orangebox is a UK market leader in the design and manufacture of contemporary office furniture. Its key focus is in the development of new products, typically task chairs, for sale into business-to-business markets. Since 1998 (when present-day Orangebox was founded) it has seen a steady increase in sales and during which time it saw cumulative increases in its turnover and job creation. Despite these successes, rising materials costs steer Orangebox to seek new business opportunities such as remanufacturing.

\subsubsection{Integrated Business Activities at Orangebox}

\section{Product design and development}

Orangebox predominantly remanufactures task seating chairs. Following research and development into the ecodesign of its products (see Prendeville et al., 2017) it has developed seating furniture with low part counts that can be easily and quickly manually dis- and reassembled. Despite the product's suitability for remanufacturing, until recently the company 
failed to recoup the value of the design investment in the absence of a suitable remanufacturing business model. Recently, it emphasises remanufacturing chairs into 'more contemporary designs' where much of the chair will be 'reused'. Key parts for remanufacturing include the chair back plastic, arms, cushions and the chair mechanism.

\section{Remanufacturing Process}

Orangebox achieves material reduction and part integration for efficient dis- and reassembly by replacing as few parts as possible during remanufacturing and maximising recycled content. The driving design requirements are durability and reliability. The chair assessment is supported by a product evaluation checklist developed in-house. The remanufacturing is undertaken by a business partner that is also a social enterprise and is informed by remanufacturing test-rigs the company developed in recent years.

\section{Value chain design and management}

Through its remanufacturing activities, Orangebox aim for a fourfold reduction in material intensity of its task chairs. The cheaper remanufactured task chairs are offered to new market segments with a full product warranty that is equivalent to a first manufactured product. Therefore, the company did not restructure its means of revenue generation, through leasing for example, but rather uses a rebate system to facilitate a reverse flow of products from its customer base and therein retains control of its products. It offers a full warranty on its remanufactured products. It uses new routes to markets for its remanufactured goods and also develops new sales and distribution channels. It strategically partnered to experiment with the possibilities of a remanufacturing business model, by selecting critically enabling partners including amenable clients, gatekeeping public sector actors and a social enterprise.

\section{Marketing and Client Relationship}

Orangebox's key clients are corporates whose brand identity drives the product aesthetics. Often, this gives rise to premature replacement of chairs based on the corporate brand, which is reflected in the color schemes of the products. A key aspect of Orangebox's remanufacturing strategy is remanufacturing the chair to align the product style with a client's corporate branding. Orangebox sell its new chairs through a dealership network. Partnership with the dealership is critical for the success of its remanufacturing initiative as the dealer maintains the client relationship. 


\subsubsection{Sustainable Value Creation at Orangebox}

Material costs comprise $45 \%$ of Orangebox's total annual expenditure and it has seen its costs of materials rising year-on-year. Drivers for investing in remanufacturing include the potential to reduce its raw material costs; revenues from remanufactured products; new markets; the need for material security in the long term; positive brand value and the ability to position itself advantageously in the industry and diversify its overall business activity.

Since 2006, Orangebox has used abridged LCA to inform design decisions during product development. The main environmental impacts of office chairs occur during raw material extraction, production and end-of-life stages and therefore material strategies are critical (FIRA, 2011). A typical task chair on the UK market weighs 18-19 kg (FIRA, 2011). A recently launched Orangebox chair weighs $13 \mathrm{~kg}$ with a carbon footprint of $79.47 \mathrm{~kg} \mathrm{CO}_{2}$-eq. emissions and this is achieved through new design features and product light-weighting (see Prendeville et al., 2017).

Its partnership approach means that its remanufacturing activity provides job opportunities in-house as well as within the local business ecosystem in the Welsh valleys. Furthermore, the remanufactured goods can give new clients access to desirable products. Table 5 summarises the triple-bottom-line factors identified at Orangebox.

Table 5: Triple-bottom-line Factors at Orangebox

\begin{tabular}{|c|c|c|}
\hline Economic benefits & Environmental Benefits & Social Benefits \\
\hline $\begin{array}{ll}\text { - } & \text { New revenue } \\
\text { generation } \\
\text { (Profitability) } \\
\text { - } & \text { Access into new } \\
& \text { markets (Spin-offs) } \\
\text { - } & \text { Enhanced brand value } \\
\text { - } & \text { Material cost savings } \\
& \text { and lower production } \\
\text { costs (cost reduction) } \\
\text { - }\end{array}$ & $\begin{array}{ll}\text { - } & \text { Reduced impacts (through } \\
\text { product life extension) } \\
\text { (Product decarbonisation } \\
\text { and footprint) } \\
\text { - } & \text { Reduced material } \\
\text { consumption (Product } \\
\text { dematerialization) }\end{array}$ & $\begin{array}{ll}\text { - } & \text { Job creation } \\
\text { (Employment) } \\
\text { - } & \text { Access to high quality } \\
\text { furniture (Corporate } \\
\text { Reputation) } \\
\text { - } \\
\text { Pride in work (Corporate } \\
\text { Culture) }\end{array}$ \\
\hline
\end{tabular}

\subsection{Firm C: Philips Healthcare}

\subsubsection{Healthcare}


In 2012, at 38\% the US market was the largest medical device market globally (US Commerce Department, n.d.). The largest markets for pre-owned equipment in the healthcare industry are Western Europe, the USA and Japan and it is expected to reach $\$ 9.37$ billion by 2019 with annual growth rates between 9.2\% to 12.5\% (MarketsandMarkets, 2015; Transparency Market Research, 2012).

\subsubsection{Firm Overview}

Philips Healthcare Refurbished Systems (Philips RS) is part of the parent company Koninklijke Philips N.V. In 2012, Philips Healthcare accounted for c. $41 \%$ of the overall company sales (Annual Report, 2012). Philips Healthcare "seeks to improve lives, through meaningful innovations to improve quality of care and patients' lives" (Annual Report, 2012).

\subsubsection{Integrated Business Activities at Philips RS}

\section{Product design and development}

Philips Healthcare Interventional X-Ray (IXR) systems are designed for minimally invasive surgery. The Diamond Select Allura Xper R7 FD20/10 IXR is an upgraded system, which is carefully selected for refurbishment, updating, and testing. The most significant driver in the field of medical devices is rapid technological innovation, stimulating the market, meaning high-quality systems are frequently replaced. Therefore, a large quantity of pre-owned equipment re-enters the market, either returned to the OEM or bought by third party brokers for resale.

\section{Remanufacturing Process}

Philips RS seek to close material loops through a whole system approach to product upgrading strategies and parts harvesting, offered through its refurbishment services. Through designing for reliability and modularity it has developed and approved an upgrade system which is based on material reuse. Through refurbishment the lifespan of IXR systems can be extended by $5-10$ years.

“...we get equipment back...that has been pre-owned by hospitals...we would clean it, we will disinfect it, we will then review all the different components, parts that need to be refurbished, we will refurbish them. We will repair, we will upgrade to the requirements of the customer and then we will test it to make sure that it fulfills all the requirements and then we will pack it and it would be ready to be sent to a new customer." (Interview with Sustainability Director, 2015) 


\section{Supply chain design and management}

Philips RS sees the need for a range of value propositions that facilitate a multitude of customer needs. Philips RS has set up an internal supply chain, where it dedicated part of its operations to offer a take-back and remanufacturing service for existing medical devices. Products are retrieved from customers through a trade-in mechanism. Positive supplier relationships are critical for the success of its remanufacturing business model, as suppliers have the "knowledge of the technology" and "processes" capacities. For remanufacturing to be successful "multiple transactions" between suppliers and producers are required. These are then transported in-house, where technically skilled technicians upgrade the system, so it can re-enter the global market.

\section{Marketing and Client Relationship}

A key driver for Philips RS is the high residual value of the product, which is created through designing for reliability in the first place. This residual value is ameliorated through a trade-in service to clients. Philips RS lease a range of refurbished goods to clients, with a follow-up customer care package and a full warranty. Through refurbishment different value propositions can be offered with different types of technology at different prices. The business proposition centers around offering perceived high quality equipment available at a low cost, with a warranty that is equivalent to new. This is possible in a global market where hospital budgets are reduced and/or emerging markets are less regulated.

“...business to business one of the advantages of....those relationships is the residual value. So when you design, you design for reliability, for exploiting, if you want, all the value that you have created...residual value is very important for companies like us so once the first customer has gone through the process, through the first life cycle of the product that doesn't mean that the product cannot be used anymore, actually it has a value. “(Interview with Sustainability Director, 2015)

\subsubsection{Sustainable Value Creation at Philips RS}

Through its system upgrades, Philips RS can reduce material consumption by up to $80 \%$. In doing so, RS can improve its resource efficiency by reducing the need for raw material inputs and waste to reduce its overall environmental impacts.

IXR systems are sold for $60 \%$ to $85 \%$ of the equivalent new system price, depending on the generation of the product and the developments in its life cycle. Refurbishment is strategic 
from a marketing and market segmentation perspective. For the customer, it can save on capital expenditure, lowering costs, which in turn lowers the barrier to access health technologies. $80 \%$ of procedures do not require state-of-the-art technology and $80 \%$ of the market is satisfied with refurbished machines. Philips can foster knowledge exchange with its customers and nurture customer relationships. In addition, in this case, the system upgrade saves costs by up to $50 \%$ on the upgrade bill of materials. The upgrades provide a new revenue stream through sales and service contracts. It can also safeguard against future material scarcity issues. Table 6 summarises the triple-bottom-line factors identified at Philips RS.

Table 6: Triple-bottom-line Indicators at Philips RS

Economic benefits $\quad$ Environmental Benefits $\quad$ Social Benefits

- Revenue generation (Profitability)

- New sales markets (Spin-offs)

- Increased customer satisfaction (Brand value)

- Market segmentation (separation of state-ofthe art customer needs and standard procedures)

- Lower production costs (up to $50 \%$ on BOM) (Competitiveness)

- Material management strategy (Profitability)
- Supports parts harvesting to reduce material consumption (80\%)

(Product dematerialization and product decarbonising)
- Access to medical devices (Corporate reputation)

- Job creation (Employment)

\section{Analysis and Discussion}

\subsection{Sustainable Value Creation through Remanufacturing}

Table 7 summarises the key factors identified in the case studies in relation to triple-bottomline benefits. 


\begin{tabular}{|c|c|c|c|}
\hline & Siemens Wind Power & Orangebox & Philips Healthcare RS \\
\hline $\begin{array}{l}\text { Economic } \\
\text { Benefits }\end{array}$ & 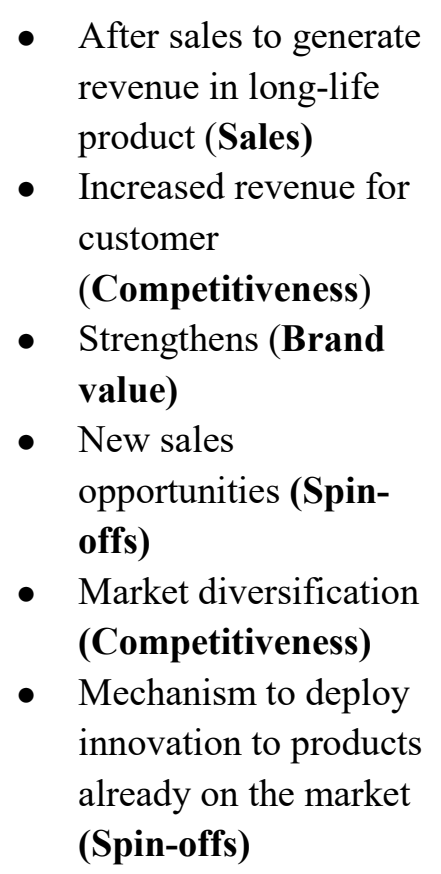 & $\begin{array}{ll}\text { - } & \text { New revenue } \\
\text { generation } \\
\text { (Profitability) } \\
\text { - } & \text { Access into new } \\
\text { markets (Spin-offs) } \\
\text { - } & \text { Strengthens (Brand } \\
\text { value) } \\
\text { - }\end{array}$ & 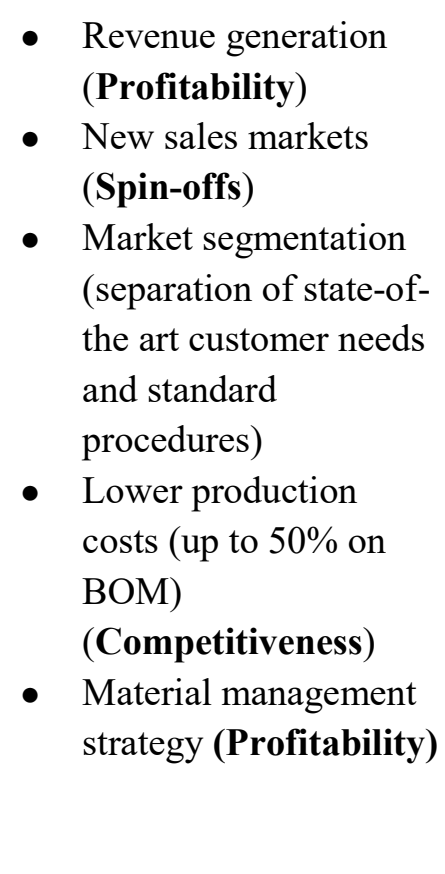 \\
\hline $\begin{array}{l}\text { Environm } \\
\text { ental } \\
\text { Benefits }\end{array}$ & $\begin{array}{ll}\text { - } & \begin{array}{l}\text { Reduced impacts } \\
\text { (Product }\end{array} \\
\text { decarbonisation) } \\
\text { - } & \text { Increase performance } \\
\text { efficiency (Climate } \\
\text { change) } \\
\text { - }\end{array}$ & 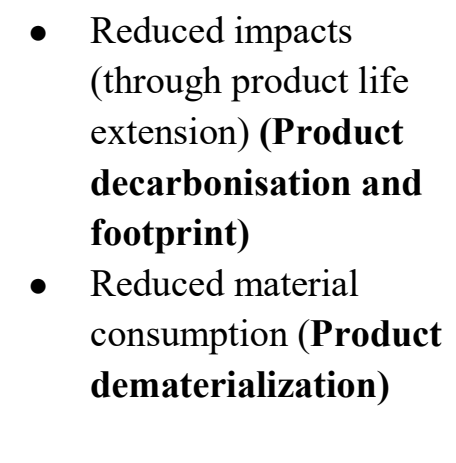 & $\begin{array}{ll}\text { - } & \text { Supports parts } \\
\text { harvesting to reduce } \\
\text { material consumption } \\
(80 \%) \\
\text { - } \\
\text { (Product } \\
\text { dematerialization and } \\
\text { product } \\
\text { decarbonisation) }\end{array}$ \\
\hline $\begin{array}{l}\text { Social } \\
\text { Benefits }\end{array}$ & $\begin{array}{ll}\text { - } & \text { Job creation } \\
\text { (Employment) } \\
\text { - } & \text { Need for skilled } \\
\text { technicians for on-site } \\
\text { installation } \\
\text { (Employment) }\end{array}$ & $\begin{array}{ll}\text { - } & \text { Job creation } \\
\text { (Employment) } \\
\text { - } & \text { Access to high quality } \\
\text { furniture (Corporate } \\
\text { Reputation) } \\
\text { - } \\
\text { Pride in work } \\
\text { (Corporate Culture) }\end{array}$ & $\begin{array}{ll}\text { - } & \text { Access to medical } \\
\text { devices at lower cost } \\
\text { (Corporate } \\
\text { reputation) } \\
\text { - } \\
\text { Job creation } \\
\text { (Employment) } \\
\text { - } & \text { Need for skilled } \\
\text { technicians for on-site } \\
\text { installation } \\
\text { (Employment) }\end{array}$ \\
\hline
\end{tabular}

The cases show a range of potential benefits of remanufacturing across triple-bottom-line indicators. A combination of commercial benefits are realised for each firm: 
- Economic benefits can be direct e.g. new sales or new financial revenues through after sales as well as indirect e.g. brand value. All three cases are seen to create new spin-offs and use remanufacturing as a means to protect or enhance their market position.

- Environmental benefits include product life extension (e.g. 5-10 years at Phillips RS) reduced material consumption and product decarbonisation as well as noise reduction in the case of SWP.

- Social benefits range from creating pride in the workplace, to building a positive global corporate reputation as well as creating new labour intensive jobs in-house or within the wider business ecosystem e.g. social enterprise collaborator with Orangebox.

Through market protection and expansion, remanufacturing is seen as a strategy to remain competitive in the long-term. In the case of Orangebox, the market opportunity was underestimated. At the outset it forecast developing remanufactured products for sales into an emerging home office market. This evolved into sales of remanufactured goods into new sectors (eg. public sector) eventually leading to the sale of remanufactured goods alongside new product into its own market. Similarly, through its approach Philips RS identifies and segments new global markets. The company's position is that its strategy is about addressing customer needs through its products. In both cases there is already a large aftermarket for these products, which both incentivizes the companies to try to control this market and reduces the perceived risk of taking on remanufacturing. For both SWP and Orangebox, there are evidenced environmental benefits of remanufacturing. By comparison across all cases new jobs are created and in many cases these jobs require technical skills and in the case of Orangebox these are local jobs. Nevertheless to ensure social benefits from remanufacturing is challenging. One approach is to partner with social enterprises, though this may not be appropriate for all types of firms. Given that remanufacturing is first an economic business opportunity for all of the firms, the need to include environmental and social indicators is validated in these cases.

\subsection{Integrated Activities towards Remanufacturing}

Table 8 summarises the key business activities and business mechanisms identified in each of the cases that facilitate the integrated remanufacturing approach. 
Table 8 Summary of Integrated Approaches and Related Mechanisms across Cases $(\mathrm{A}=$ Siemens, $\mathrm{B}=$ Orangebox, $\mathrm{C}=$ Philips RS)

\author{
Integrated Business Mechanisms used by Firm (A, B, C) \\ Activities (Fig 1)
}

\author{
Business benefit of Mechanism \\ to achieving Integrated \\ Approach
}

\begin{tabular}{|c|c|c|}
\hline $\begin{array}{l}\text { Product design \& } \\
\text { development }\end{array}$ & $\begin{array}{l}\text { Design criteria (e.g. durability, } \\
\text { reliability, modularity) (A, B, C) } \\
\text { - Upgradability strategy (relevant } \\
\text { products, full product/add-ons) to } \\
\text { facilitate parts harvesting and } \\
\text { refurbishment (A, C) } \\
\text { - } \\
\text { Product evaluation criteria (A, C) } \\
\text { Ecodesign / LCA / Environmental } \\
\text { Product Declarations (A, B) }\end{array}$ & 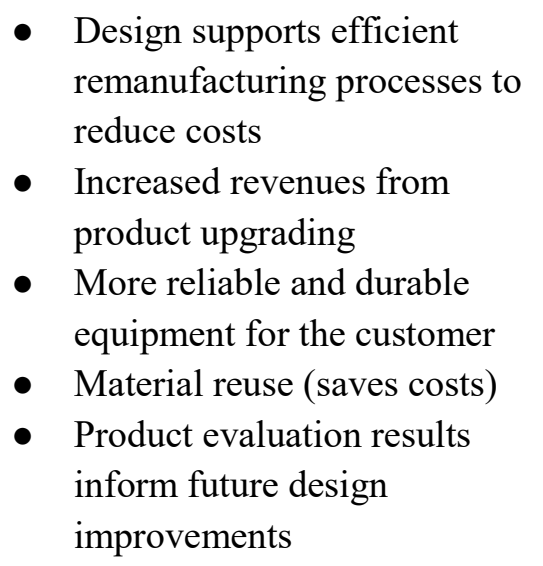 \\
\hline $\begin{array}{l}\text { Remanufacturing } \\
\text { Process }\end{array}$ & $\begin{array}{l}\text { - Product evaluation criteria }(\mathrm{A}, \mathrm{C}) \\
\text { - } \\
\text { cystematic process (onsite / offsite at } \\
\text { - } \text { Cleaning through to testing }(\mathrm{B}, \mathrm{C}) \\
\text { - } \\
\text { Process developed to customer } \\
\text { requirements }(\mathrm{C}) \\
\text { - } \\
\text { Part integration improves process } \\
\text { efficiency }(\mathrm{A}, \mathrm{B}, \mathrm{C}) \\
\text { - } \\
\text { Partnering for technologies/ } \\
\text { processes/skills/labour }(\mathrm{B})\end{array}$ & $\begin{array}{l}\text { - } \text { Quality control } \\
\text { - Optimisation of process } \\
\text { - Increased knowledge about } \\
\text { - } \text { product design and usage } \\
\text { Partnership saves on labour } \\
\text { costs }\end{array}$ \\
\hline $\begin{array}{l}\text { Value chain design } \\
\text { and management }\end{array}$ & $\begin{array}{l}\text { - Full product warranty }(\mathrm{A}, \mathrm{B}, \mathrm{C}) \\
\text { - } \\
\text { agreem sales alongside new service } \\
\text { - Service agreements / Rebates / Trade- } \\
\text { in mechanism facilitate product } \\
\text { return }(\mathrm{B}, \mathrm{C}) \\
\text { - } \\
\text { Service contract facilitates } \\
\text { remanufacturing business element } \\
\text { (C) } \\
\text { - } \\
\text { - } \text { Mnvironmental assessment (A, B) } \\
\text { - }\end{array}$ & $\begin{array}{l}\text { Increased value and incentive } \\
\text { - } \quad \text { Ner the customer } \\
\text { streams for business } \\
\text { - Increased product recovery } \\
\text { and material reuse } \\
\text { - Management of } \\
\text { environmental impacts }\end{array}$ \\
\hline $\begin{array}{l}\text { Customer marketing } \\
\text { \& behaviour }\end{array}$ & $\begin{array}{l}\text { - Customer sales incentive of reduced } \\
\text { noise and increased energy output } \\
\text { (A) }\end{array}$ & $\begin{array}{l}\text { - Increased customer benefits } \\
\text { (efficiency increases potential } \\
\text { revenue, noise reduction }\end{array}$ \\
\hline
\end{tabular}


- Service agreements maintain lines of communication (B)

- Customer criteria: quality, environmental compliance and/or regulations $(\mathrm{C})$

- Ecodesign / LCA / Environmental Product Declarations (A, B) improves societal acceptance)

- Increased customer contact

- 'Eco-products' offer to proenvironmental buyers, improves corporate identity

- Maintains compliance for producers and clients

Orangebox had been investing in design improvements for many years prior to its systematic approach to testing remanufacturing through its remanufacturing pilot study. This meant that it was missing out on value invested in its design that could be recouped through remanufacturing. It took time for the firm to assimilate its remanufacturing knowledge and capabilities as well as for the appropriate conditions for remanufacturing to be established. Its entry point to remanufacturing (initiated with its ecodesign research and development) and catalysed by growing material prices, eventually led it to develop its business approach aspects. In contrast, the SWP PCUP is not designed with remanufacturing in mind, yet the business scenario leads the company to remanufacturing on-site at the client's premises. Thus firms can have multiple entry-points into remanufacturing and a core set of capabilities (Fig. 2 ) need to be developed in unison for that remanufacturing activity to be successful.

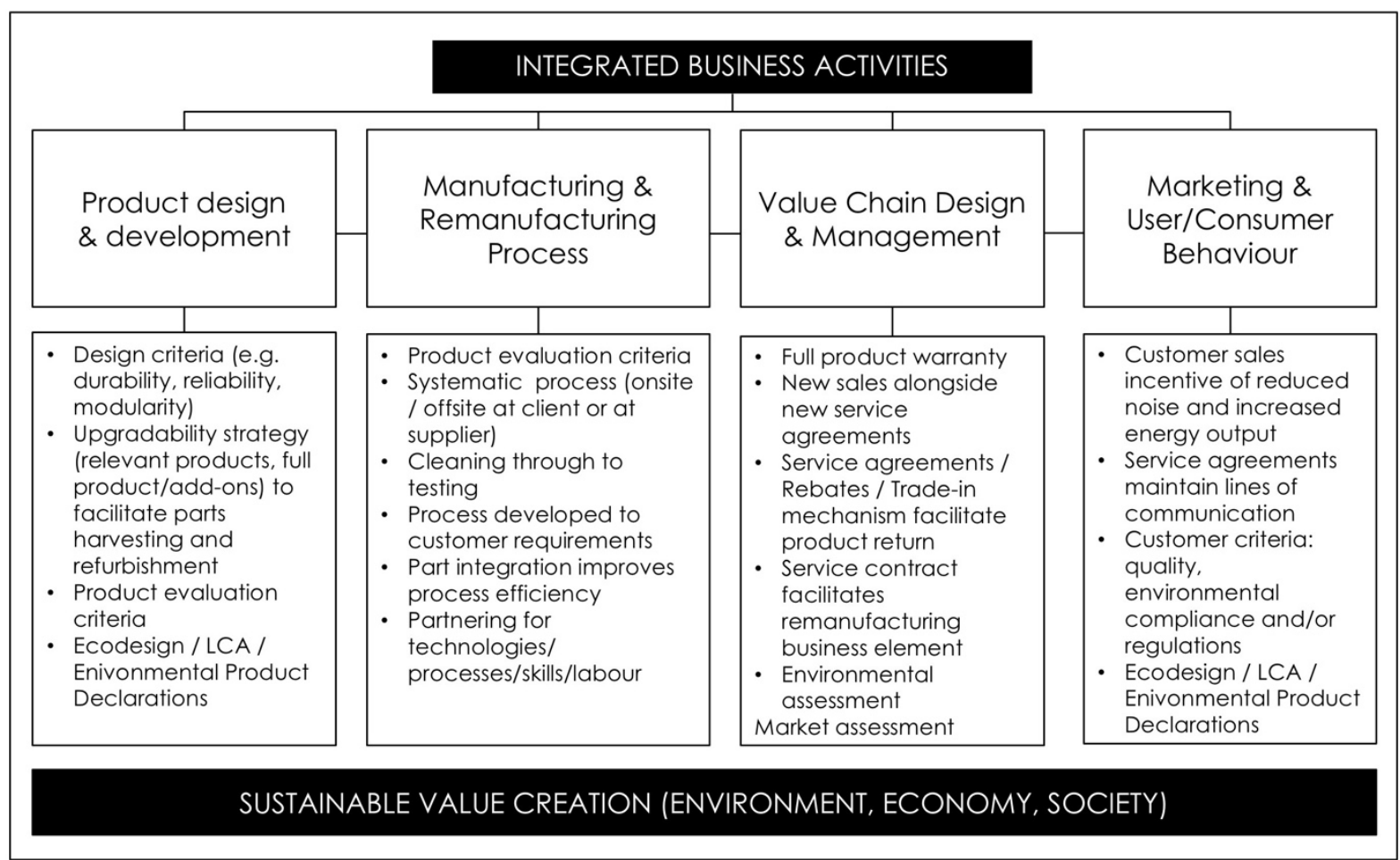


Fig. 2 Integrated Business Activities and Business Mechanisms required for Triple-bottom-line Sustainable Value Creation (Building on Lieder \& Rashid, 2016; Brundtland, Elkington 1997, Ellen MacArthur Foundation 2013)

Financial restructuring and/or having an appropriate financial transaction is critical for these businesses and in the cases of both Orangebox and Philips RS, the provision of multiple, layered value propositions is critical for the firm to manage risks. Product returns are facilitated through rebate systems or product return services. In the case of Orangebox, leasing was a much discussed but unsuitable approach due to its dealership structure of selling. Therefore, the company opted for a rebate system. This illustrates that some financial tools may be more or less suitable to some types of firms and/or some sectors. Companies need to evaluate the market and work with clients and other business partners to assess the suitability of a given financial model.

The case of SWP casts remanufacturing in a new light because current perspectives on remanufacturing overlook the immobile nature of some types of products (such as wind turbines) which have high capital costs and as such can be suited to on-site remanufacturing. Such a scenario can be distinguished from industrial remanufacturing process, which typically involve a reverse flow of products back to a remanufacturing plant. This is limiting for firms, who may overlook remanufacturing if it is not already common in a given sectors. This case shows how remanufacturing can mitigate against the need for whole product upgrades as well as bringing innovation to the client. In contrast, at both Orangebox and Phillips RS, the market for used products is vibrant and therefore in many ways it is a low risk approach, as well as a tool to control its products and reputation. In summary, overall the firms stand to gain in these instances and doing remanufacturing in scenarios with less market incentives would be challenging. Nevertheless, other companies can learn from the case studies and business approaches discussed in this article.

\subsection{Remanufacturing replacing virgin manufacturing?}

At the time of writing, remanufacturing intensity (ratio of remanufacturing to manufacturing) is only $1.9 \%$ in Europe, with similar levels in the US (Vogtlander et al., 2017). A lot of work and positive cases are needed to accelerate the uptake of remeanufacturing as an important strategy in the Circular Economy. The cases show that remanufacturing is seen as a new business opportunity to tap into new markets. However, to avoid 'circular economy rebound' (Zink \& Geyer, 2017) where circular economy activities in fact lead to more consumption of 
materials and products, more drastic changes are needed to the industry and policy landscape. As such, the emergent cases are only the starting point in the circular economy transition (Blomsma \& Brennan, 2017) but an important one, demonstration that remanufacturing has business and environmental potential, while also potentially creating social value, if consciously set up to drive positive impacts. Such a transition would require strategies of 'sufficiency', which is being explored at a company as well as country basis (Bocken \& Short, 2016) and policies questioning consumerism and planned obsolescence that drive industrybehaviour towards more sufficiency-oriented business models (Maitre-Ekern \& Dalhammar, 2016)

\section{Conclusion}

This article sought to answer the question: Can an integrated perspective on remanufacturing drive sustainable value creation? The cases show that remanufacturing has the potential to create sustainable value across triple-bottom-line indicators by increasing sales, competitiveness, brand value, offer new sales opportunities, reduce environmental impacts of offered products through efficiency increase and material reduction and create new jobs and employment possibilities.

However, each of the firms are investing in remanufacturing predominantly for profitability and market protection measures underpinned by life cycle assessment considerations.

Therefore, an integrated approach that proactively manages environmental impacts as well as taking account for social factors is critical. The suite of factors identified in this study can act as a basis to support further work in this area.

Interventions across each of the integrated activities are required for remanufacturing to be successful and therein realise triple-bottom-line benefits. In a $\mathrm{CE}$, remanufacturing is often perceived as the most desirable innovation strategy to slow resource loops. If remanufacturing is to occupy a central role in a future $\mathrm{CE}$ it needs to be considered from a series of complementary and synchronous business activities. This work contributes to the understanding of remanufacturing by developing a model for integrated business activities that includes a set of business mechanisms that companies can adopt to support an integrated remanufacturing approach.

The paper is aware of that to avoid 'circular economy rebound', where circular economy activities in fact lead to more consumption of materials and products, more drastic changes are needed to the industry and policy landscape. As such, the emergent cases are only the starting 
point in the circular economy transition, but an important one, demonstration that remanufacturing has business and environmental potential, while also potentially creating social value, if consciously set up to drive positive impacts. Such a transition would require strategies of 'sufficiency', and policies questioning consumerism and planned obsolescence that drive industry-behaviour towards more sufficiency-oriented business models.

The article shows cases from three different industries, which needs to be taken into consideration when assessing the cases presented. However, common factors have been identified and the findings from the study can inform the activities of other firm's tailored approaches.

\section{Acknowledgements}

This research is supported by the European Remanufacturing Network (ERN) funded by the European Union under the H2020 Framework Programme. Grant agreement number 645984 and by the European Union EIT Raw Materials KIC programme, projects RUN and ReUK (both on remanufacturing), 2016-17, project numbers 15023 and 15078. The authors are grateful to the participating companies.

\section{References}

Achterberg, E., Hinfelaar, J., Bocken, N.M.P. 2016. Master circular business models with the Value Hill. White paper, September 2016

Agrawal, S., Singh, R.K. \& Murtaza, Q. 2016. Triple-bottom-line performance evaluation of reverse logistics. Competiveness Review 26(3). 289-310.

Ali N. S., N.F. Khairuddin, and S. Zainal Abidin. 2013. Upcycling: re-use and recreate functional interior space using waste materials. In DS 76 Proceedings of E\&PDE 2013 the 15th International Conference on Engineering and Product Design Education, 5-6 September, Dublin, Ireland.

Allenby, B. 2006. The ontologies of industrial ecology? Progress in Industrial Ecology, an International Journal 3(1-2): 28-40.

Allwood, J.M. 2014. Squaring the Circular Economy: The Role of Recycling within a Hierarchy of Material Management Strategies. In: Handbook of Recycling: State-of-theart for Practitioners, Analysts, and Scientists. Edited by M. Reuter and E. Worrell Chp. 30 pp. 445-477. Waltham, MA, USA. Elsevier.

Allwood, J.M., Ashby, M.F., Gutowski, T.G. \& Worrell, E. 2011. Material efficiency: A white paper. Resources, Conservation and Recycling 55. 362-381.

Allwood, J. M., J. M. Cullen, M. A. Carruth, D. R. Cooper, M. McBrien, R. L. Milford, M. C. Moynihan, and A. CH Patel. 2012. Sustainable materials: with both eyes open. Cambridge: UIT Cambridge, 2012. Free download from www.withbotheyesopen.com. 
Andersen, M.S. 2006. An introductory note on the environmental economics of the circular economy. Sustainability Science 2(1): 133-140. http://dx.doi.org/10.1007/s11625-0060013-6.

Bakker, C., F. Wang, J. Huisman, and M. den Hollander. 2014. Products that go round: exploring product life extension through design. Journal of Cleaner Production 69: 1016. http://www.sciencedirect.com/science/article/pii/S0959652614000419.

Barquet, A.P., Seidel, J., Seliger, G. and Kohl, H. 2016. Sustainability Factors for PSS Business models. Procedia CIRP 47 (436-441)

Bazargan, A. and G. McKay. 2012. A review - Synthesis of carbon nanotubes from plastic wastes. Chemical Engineering Journal 195-196: 377-391. http://www.sciencedirect.com/science/article/pii/S1385894712004378.

Biswas, W.K., V. Duong, P. Frey, and M.N. Islam. 2013. A comparison of repaired, remanufactured and new compressors used in Western Australian small- and mediumsized enterprises in terms of global warming. Journal of Remanufacturing 3(1): 1-7.

Blomsma, F. and Brennan, G. 2017. The Emergence of Circular Economy: A New Framing Around Prolonging Resource Productivity. Journal of Industrial Ecology

Bocken, N., Short, S. 2016. Towards a sufficiency-driven business model: Experiences and opportunities. Environmental Innovation and Societal Transitions, 18, (41-61).

Bocken, N.M.P., de Pauw, I., van der Grinten, B., Bakker, C. 2016. Product design and business model strategies for a circular economy. Journal of Industrial and Production Engineering, 32 (1), 67-81.

Bocken, N., Short, S., Rana, P., Evans, S. 2013. A value mapping tool for sustainable business modelling. Corporate Governance, 13 (5), 482 - 497

Bocken, N.M.P., Olivetti, E.A., Cullen, J.M., Potting, J. and Lifset, R. 2017. Taking the Circularity to the Next Level: A Special Issue in the Circular Economy. Journal of Industrial Ecology.

British Standards Institute. 2010. BS 8887-220:2010 - Design for manufacture, assembly, disassembly and end-of-life processing (MADE) and BS 8887-2:2009 - Terms and definitions, BS 8887-1:2006 - General concepts, process and requirements. Produced by British Standards Institute technical product specification committee (TDW/004/0-/05 Design for MADE BSI), British Standards Publications, Southam, UK.

BTM Navigant. 2015. World Wind Energy Market Update 2015, s.1.: BTM Navigant.

Centre for European Policy Studies. 2014. The EU furniture market situation and a possible furniture products initiative. Final report Submitted to the European Commission DG Enterprise and Industry.

Chertow, M.R. 2000. Industrial Symbiosis: Literature and Taxonomy. Annual Review of Energy and the Environment 25(1): 313-337. http://www.annualreviews.org/doi/abs/10.1146/annurev.energy.25.1.313.

Chertow, M. and J. Ehrenfeld. 2012. Organizing Self-Organizing Systems: Toward a Theory of Industrial Symbiosis. Journal of Industrial Ecology 16(1): 13-27.

Cooper, T. Inadequate Life? Evidence of Consumer Attitudes to Product Obsolescence. Journal of Consumer Policy 27(4): 421-449. http://dx.doi.org/10.1007/s10603-0042284-6. 
Cullen, J.M. 2017. Circular Economy. Theoretical Benchmark or Perpetual Motion Machine? Journal of Industrial Ecology.

Das, K. \& Posinasetti, N. R., 2015. Addressing environmental concerns in closed loop supply chain design and planning. International Journal of Production Economics, Volume 163, pp. 34-47.

Dutta, P., Das, D., Schultmann, F. \& Fröhling, M., 2016. Design and planning of a closedloop supply chain with three way recovery and buy-back offer. Journal of Cleaner Production, Volume 135, pp. 604-619.

Daaboul, J., Le Duigou, J., Penciuc, D. \& Eynard, B., 2014. Reverse logistics network design: a holistic life cycle approach. Journal of Remanufacturing, 4(7).

Elkington, J. 1997. Cannibals with Forks: The triple-bottom-line of 21 st century business. Capstone Publishing Ltd.

Ellen MacArthur Foundation. 2013a. Towards the Circular Economy 1: an economic and business rationale for an accelerated transition.

Ellen MacArthur Foundation. 2013b. Towards the Circular economy: opportunities for the consumer goods sector.

Ellen MacArthur Foundation. 2015a. Growth within: a circular economy vision for a competitive Europe.

Ellen MacArthur Foundation. 2015b. Potential for Denmark as a Circular Economy - A Case Study from: Delivering the Circular Economy - A Toolkit for Policy Makers.

Esty, D.C. and M.E. Porter. 1998. Industrial Ecology and Competitiveness. Journal of Industrial Ecology 2(1): 35-43.

Evans, S., Fernando, L. and Yang, M. 2017. Sustainable Value Creation - From Concept Towards Implementation. Sustainable Manufacturing, pp. 203-220

European Remanufacturing Network. 2015. Remanufacturing Market Study (645984). Available at: http://www.remanufacturing.eu/european-remanufacturing-industryestimated-at-e30bn-with-potential-to-triple-by-2030/ Accessed: $15^{\text {th }}$ Feb. 2015.

Fukushige, S., Yamamoto, K. \& Umeda, Y., 2012. Lifecycles scenario design for product end-of-life strategy. Journal of Remanufacturing, 2(1).

Furniture Industry Research Association. 2011. A study into the feasibility of Benchmarking carbon footprints of furniture products.

Frosch, R A., and N. E. Gallopoulos. 1989. Strategies for manufacturing. Scientific American 261(3): 144-152.

Garg, K., Kannan, D., Diabat, A. \& Jha, P., 2015. A multi-criteria optimization approach to manage environmental issues in closed loop supply chain network design. Journal of Cleaner Production, Volume 100, pp. 297-314.

Geissdoerfer, M., Savaget, P., Bocken, N., Hultink, E. The Circular Economy - a new sustainability paradigm? Journal of Cleaner Production (in press).

Georgiadis, P. \& Besiou, M., 2008. Sustainability in electrical and electronic equipment closed-loop supply chains: A System Dynamics approach. Journal of Cleaner Production, Volume 16, pp. 1665-1678.

Giuntini, R., 2003. Remanufacturing: The next great opportunity for boosting US productivity. Business Horizons , pp. 41-48. 
Gong, J., J. Liu, X. Wen, Z. Jiang, X. Chen, E. Mijowska, and T. Tang. 2014. Upcycling Waste Polypropylene into Graphene Flakes on Organically Modified Montmorillonite. Industrial \& Engineering Chemistry Research 53(11): 4173-4181. http://dx.doi.org/10.1021/ie4043246.

Govindan, K. \& Soleimani, H., 2016. A review of reverse logstics and closed-loop supply chains: a Journal of Cleaner Production focus. Journal of Cleaner Production, pp. 1-14.

Govindan, K., Soleimani, H. \& Kannan, D., 2015. Reverse logistics and closed-loop supply chain: A comprehensive review to explore the future. European Journal of Operational Research, Volume 240, pp. 603-625.

Graedel T, Nassar N (2013) The criticality of metals: A perspective for geologists. Ore Deposits in an Evolving Earth, eds Jenkin GRT, et al. (Geological Society, London).

Graedel, T., Barr, R., Chandler, C., Chase, T., Choi, J., Christoffersen, L., Friedlander, E., Henly, C., Jun, C., Nassar, N., Schechner, D., Warren, S., Yang, M-Y. \& Zhu, C. (2012). Methodology of Metal Criticality Determination. Environmental Science \& Technology 46 (2) pp. 1063-1070.

Guide, V., T. Harrison, and L. Van Wassenhove. 2003. The Challenge of Closed-Loop Supply Chains. Interfaces 33(6): 2-6.

Guide, V. \& Van Wassenhove, L. 2009. The Evolution of Closed-Loop Supply Chain Research. Operations Research 57 (1): 10-18.

Guiltinan, J. 2009. Creative destruction and destructive creations: Environmental ethics and planned obsolescence. Journal of Business Ethics 89(SUPPL. 1): 19-28.

Guo, S., Aydin, G. \& Souza, G. C., 2014. Dismantle or remanufacture. European Journal of Operational Research, Volume 233, pp. 580-583.

Gutowski, T. 2011. Manufacturing and the Science of Sustainability. CIRP Keynote 2011.

Gutowski, T., Sahni, S., Boustani, A. \& Graves, S. 2011. Remanufacturing and Energy Savings. Environmental Science and Technology 45 (10): 4540-4547.

GWEC (2015). Global Wind Report 2014, s.1.: Global Wind Energy Council.

Harris, F., H. Roby, and S. Dibb. 2015. Sustainable clothing: challenges, barriers and interventions for encouraging more sustainable consumer behaviour. International Journal of Consumer Studies: n/a-n/a. http://dx.doi.org/10.1111/ijcs.12257.

Hatcher, G.D., W.L. Ijomah, and J.F.C. Windmill. 2011. Design for remanufacture: a literature review and future research needs. Journal of Cleaner Production 19(17-18): 2004-2014.

Hatcher, G.D., Ijomah, W.L. \& Windmill, J.F.C. 2014. A network model to assist 'design for remanufacture' integration into the design process. Journal of Cleaner Production 64: 244253

Helms, S. \& Goldstein, J., 1999. Book review - The Remanufacturing Industry: Hidden Giant \& Remanufacturing: The Ultimate Form of Recycling. Journal of Industrial Ecology, 3(3), pp. 189-192.

Ijomah, W. L., Bennett, J. P. \& Pearce, J., 1999. Remanufacturing: Evidence of Environmentally Conscious Business Practice in the UK. IEEE, pp. 192-196.

International Energy Agency. 2013. Technology Roadmap - Wind Energy 2013 edition. International Energy Agency.

https://www.iea.org/publications/freepublications/publication/Wind_2013_Roadmap.pdf 
Ismail, N. H., Mandil, G. \& Zwolinski, P., 2014. A remanufacturing process library for environmental impact simulations. Journal of Remanufacturing, 4(2).

Kafuku, J.M., Saman, M.Z.M., Yusof, S.M., Sharif, S., \& Zakuan, N.. 2015. Investment Decision Issues from Remanufacturing System Perspective: Literature Review and Further Research. Procedia CIRP 26: 589-594.

Kaldellis, J.K. and D. Zafirakis. 2011. The wind energy (r)evolution: A short review of a long history. Renewable Energy 36(7): 1887-1901. http://www.sciencedirect.com/science/article/pii/S0960148111000085.

Kalorama Information (2012). The Global Market for Medical Devices, s.1.: Kalorama Information.

Keith S., M., Silies 2015. New life luxury: upcycled Scottish heritage textilesnull. International Journal of Retail \& Distribution Management 43(10/11): 1051-1064.

Kircherr, J., Piscicelli, L., Bour, R., Kostense-Smit, E., Muller, J., Huibrechtse-Truijens, A. \& Hekkert, M. (2018). Barriers tot he Circular Economy: Evidence fro, the European Union (EU). Ecological Economics 150, pp. 264-272.

Korhonen, J., Honkasalo, A. \& Seppäla, J. (2018). Circular Economy: The Concept and its Limitations. Ecological Economics 145, pp. 37-46.

Lewandowski, M. (2016). Designing the business models for circular economy - Towards the conceptual framework. Sustainability, 8 (43): 1-28.

Lieder, M. \& Rashid, A. 2016. Towards circular economy implementation: a comprehensive review in context of manufacturing industry. Journal of Cleaner Production 115. 36-51

Lifset, R. and T.E. Graedel. 2002. Industrial ecology: goals and definitions. A Handbook of Industrial Ecology: 3-15. Eds - R.U. Ayres \& L. W. Ayres. Northampton.

Lindahl, M., Sundin, E. \& Östlin, J., 2006. Environmental Issues within the Remanufacturing Industry. Leuven, 13th CIRP International Conference on Life Cycle Engineering.

Linder, M. \& Williander, M., 2015. Circular Business Model Innovation: Inherent Uncertainties. Business Strategy and the Environment.

Liu, Z., T. Li, Q. Jiang, and H. Zhang. 2014. Life Cycle Assessment-based Comparative Evaluation of Originally Manufactured and Remanufactured Diesel Engines. Journal of Industrial Ecology 18(4): 567-576.

Lombardi, D.R. and P. Laybourn. 2012. Redefining Industrial Symbiosis. Journal of Industrial Ecology 16(1): 28-37. http://dx.doi.org/10.1111/j.1530-9290.2011.00444.x.

Lund, R., 1996. The Remanufacturing Industry: Hidden Giant. Boston: Boston University Press.

Maitre-Ekern, E., \& Dalhammar, C. 2016. 'Regulating Planned Obsolescence: A Review of Legal Approaches to Increase Product Durability and Reparability in Europe'. Review of European, Comparative \& International Environmental Law, 25(3), 378-394.

Magretta, J. 2002. Why business models matter. Harvard Business Review 80(5): 86-92.

Make Consulting. 2015. Global Wind Turbine OEM 2014 Market Share analysis report, s.1.: Make Consulting.

MarketsandMarkets (2015). Refurbished Medical Equipment Market (Ultrasound, MRI, CT Scanner, C-Arm, Nuclear Imaging Systems, Heart-Lung Machine, Surgical, CO2 
Monitor, Patient Monitor, Pulse Oximeter, AED Defibrillator, Cath Labs, Stretchers, Endoscopy) - Global Forecasts to 2019 , s.1.: MarketsandMarkets.

Matsumoto M, Ijomah W,. 2013. Remanufacturing. In: Kauffman J, Lee KM, editors. Handbook of Sustainable Engineering. 389-408.

McDonough, W. and M. Braungart. 2008. 3 Remaking the way we make things: creating a new definition of quality with cradle-to-cradle design. The International Handbook on Environmental Technology Management: 33.

Murray, A., K. Skene, and K. Haynes. 2015. The Circular Economy: An Interdisciplinary Exploration of the Concept and Application in a Global Context. Journal of Business Ethics.

Mutha, A. \& Pokharel, S., 2009. Strategic network design for reverse logistics and remanufacturing using new and old product modules. Computers \& Industrial Engineering, Volume 56, pp. 334-346.

Nasr, N. and M. Thurston. 2006. Remanufacturing : A Key Enabler to Sustainable Product Systems. Proceedings of LCE: 15-18.

Opresnik, D. \& Taisch, M., 2015. The manufacturer's value chain as a service - the case of remanufacturing. Journal of Remanufacturing, 5(2).

Östlin, J. 2008. On remanufacturing systems: analyzing and managing material flows and remanufacturing processes. Dissertation, Linköping University.

Peck, D., Kandachar, P., and Tempelman, E. 2015. Critical materials from a product design perspective. Materials \& Design 65: 147-159.

Peck. D, Prometheus Missing: Critical Materials and Product Design, Delft University of Technology, 2016.

Pigosso, D.C.A., E.T. Zanette, A.G. Filho, A.R. Ometto, and H. Rozenfeld. 2010. Ecodesign methods focused on remanufacturing. Journal of Cleaner Production 18(1): 21-31. http://www.sciencedirect.com/science/article/pii/S0959652609002820.

Pisello, A.L. and F. Cotana. 2013. Corporate Sustainability. In , ed. by Paolo Taticchi, Paolo Carbone, and Vito Albino, 265-280. Berlin, Heidelberg: Springer Berlin Heidelberg.

Pokharel, S. \& Mutha, A., 2009. Perspectives in reverse logistics: A review. Resourcer, Conservation and Recycling, Volume 53, pp. 175-182.

Porter, M.E. and C. van der Linde. 1995. Toward a New Conception of the EnvironmentCompetitiveness Relationship. Journal of Economic Perspectives 9(4): 97-118. http://www.aeaweb.org/articles.php?doi=10.1257/jep.9.4.97.

Prendeville, Sharon M, Frank O Connor, Nancy M P Bocken, and Conny Bakker. 2017. "Uncovering Ecodesign Dilemmas : A Path to Business Model Innovation." Journal of Cleaner Production 143. Elsevier Ltd: 1327-39. doi:10.1016/j.jclepro.2016.11.095.

Prendeville, S., Cherim, E. and Bocken, N. 2017. Circular Cities: Mapping Six Cities in Transition. Environmental Innovations and Societal Transitions.

Qiang, Q. (., 2015. The closed-loop supply chain network with competition and design for remanufactureability. Journal of Cleaner Production, Volume 105, pp. 348-356.

Quariguasi-Frota-Neto, J. and J. Bloemhof. 2012. An Analysis of the Eco-Efficiency of Remanufactured Personal Computers and Mobile Phones. Production and Operations Management 21(1): 101-114. http://dx.doi.org/10.1111/j.1937-5956.2011.01234.x. 
Rashid, A., Asif, F.M.A., Krajnik, P, \& Nicolescu, C.M.. (2013) Resource conservative manufacturing: An essential change in business and technology paradigm for sustainable manufacturing. Journal of Cleaner Production 57: 166-177.

Richardson, J., 2008. The business model: an integrative framework for strategy execution. Strategic change, 17, 133-144.

Richardson, M. 2011. Design for reuse: Integrating upcycling into industrial design practice. International Conference on Remanufacturing (Ipcc 2006): 1-13.

Reijnders, L. 2008. Are emissions or wastes consisting of biological nutrients good or healthy? Journal of Cleaner Production 16(10): 1138-1141.

Short, S.W., N.M.P. Bocken, C.Y. Barlow, and M.R. Chertow. 2014. From Refining Sugar to Growing Tomatoes. Journal of Industrial Ecology 18(5): 603-618.

Siemens. 2015. Siemens $A G$. [Online] Available at: www.energy.siemens.com/nl/en/renewable-energy/wind-power/wind-turbinetechnology/blades.htm Accessed 3 February 2016.

Siemens Wind Power 2014. Environmental Product Declaration: A clean energy solutionfrom cradle to grave, Brande: Siemens Wind Power.

Siemens Wind Power. 2015. Siemens AG - Blade Technology. [Online] Available at: www.energy.siemens.com/nl/en/renewable-energy/wind-power/wind-turbinetechnology/blades.htm\#content=Aerodynamic\%20optimization Accessed 3 February 2016.

Slade, G. 2007. Made to Break: Technology and Obsolescence in America. Harvard University Press, Cambridge.

Slaper, T. F. \& Hall, T.J. 2011. The Triple-bottom-line: What It Is and How Does It Work?. Indiana Business Review 80(1). 4-8

Stahel, W. 1994. The utilization-focused service economy: Resource efficiency and productlife extension. The Greening of Industrial Ecosystems, 178-190.

Steinhilper, R., 1998. Remanufacturing: The Ultimate Form of Recycling. 108: Fraunhofer IRB Verlag.

Steinhilper, R. and M. Hieber. 2001. Remanufacturing-the key solution for transforming "downcycling" into "upcycling" of electronics. 2001 Ieee International Symposium on Electronics and the Environment: 161-166.

Steinhilper, R. and M. Hieber. 2014. Manufacturing or remanufacturing? Decision management and success factors. Berlin.

Stubbs, W., Cocklin, C., 2008. Conceptualizing a Sustainability Business Model. Organization \& Environment 21, 103-127.

$\mathrm{Su}, \mathrm{B}$., A. Heshmati, Y. Geng, and X. Yu. 2013. A review of the circular economy in China: moving from rhetoric to implementation. Journal of Cleaner Production 42: 215-227.

Sundin, E. 2004. Product and Process Design for Successful Remanufacturing. Ph.D. Dissertation, Linköping's Universitet.

Sung, K., Cooper, T. and Kettley, S.. 2014. Individual upcycling practice: exploring the possible determinants of upcycling based on a literature review. Sustainable Innovation 2014, 19th International Conference. 3-4 ${ }^{\text {th }}$ November, Copenhagen, Denmark. http://irep.ntu.ac.uk/2559/. 
Sung, K. 2015. A Review on Upcycling : Current body of literature, knowledge gaps and a way forward. In Part I, ICEES 2015: 17th international conference on environmental and earth sciences 17(4): 28-40. 13-14 April, Venice, Italy.

Svensson, G., Høgevold, N., Ferro, C., Varela, J.C.S., Pardin, C. \& Wagner, B. 2016. A Triple-bottom-line Dominant Logic for Business Sustainability: Framework and Empirical Findings

Transparency Market Research (2012). Refurbished Medical Equipment Market - Global Industry Analysis, Size, Share, Growth, Trends and Forecast 2012 - 2018, s.1.: Transparency Market Research.

Umeda, Y., Kondoh, S., Shimomura, Y. \& Tomiyama, T. (2005). Development of design methodology for upgradeable products based on function-behavior-state modelling. Artificial Intelligence for Engineering Design, Analysis and Manufacturing 19 (3) pp $161-182$

Umweltbundesamt (UBA) (2016). Einfluss der Nutzungsdauer von Produkten auf ihre Umweltwirkung: Schaffung einer Informationsgrundlage und Entwicklung von Strategien gegen „Obsoleszenz" Umweltbundesamt. Germany

United States Commerce Department (n.d.). SelectUSA. [Online] Available at: http://selectusa.commerce.gov/industry-snapshots/medical-device-industry-unitedstates.html[Accessed 3 February 2016].

United States International Trade Commission, 2012. Remanufactured Goods: An Overview of the U.S. and Global Industries, Markets, and Trade. Available at: https://www.usitc.gov/publications/332/pub4356.pdf [accessed 8 November 2016]

United States International Trade Commission Report October 2012, p21.

Visiongain. 2013. Medical Devices Industry and Market Prospects 2013-2023, s.1.: Visiongain.

Vogtlander, Joost G., Scheepens, Arno E., Bocken, Nancy M.P. \& Peck, David. 2017. Combined analyses of costs, market value and eco-costs in circular business models: eco-efficient value creation in remanufacturing. Journal of Remanufacturing 7(1): pp. 117.

Wang, F., J. Huisman, A. Stevels, and C.P. Baldé. 2013. Enhancing e-waste estimates: Improving data quality by multivariate Input-Output Analysis. Waste Management 33(11): 2397-2407.

http://www.sciencedirect.com/science/article/pii/S0956053X13003073.

Wells, P.E. and M. Seitz. 2005. Business models and closed-loop supply chains: a typology. Supply Chain Management 10(4): 249-251.

Wang, J. and M. Chen. 2013. Remanufacturing process for used automotive electronic control components in China. Journal of Remanufacturing 3(1): 1-17. http://dx.doi.org/10.1186/2210-4690-3-9.

Xiong, Y., Zhao, Q. \& Zhou, Y., 2016. Manufacturer-remanufacturing vs supplierremanufacturing in a closed-loop supply chain. International Journal of Production Economics, Volume 176, pp. 21-28.

Yang, S. S., Ong, S. K. \& Nee, A. Y. C., 2015. Towards implementation of DfRem into the product development process. Procedia CIRP, Volume 26, pp. 565-570. 
Zhang, H., J. Feng, W. Zhu, C. Liu, S. Xu, P. Shao, D. Wu, W. Yang, and J. Gu. Chronic toxicity of rare-earth elements on human beings. Biological Trace Element Research 73(1): 1-17. http://dx.doi.org/10.1385/BTER:73:1:1.

Zink, T., Geyer, R. 2017. Circular economy rebound. J. Ind. Ecol. 21, 593-602. doi: $10.1111 /$ jiec. 12545

Zott, C., R. Amit, and L. Massa. 2011. The business model: Recent developments and future research. Journal of Management 37(4): 1019-1042.

http://jom.sagepub.com.ezproxy.liberty.edu:2048/content/37/4/1019. 